OPEN ACCESS

Edited by:

Hayley Jane Fowler,

Newcastle University, United Kingdom

Reviewed by:

Xander Wang

University of Prince Edward Island,

Canada

Martin Stendel,

Danish Meteorological Institute (DMI),

Denmark

${ }^{*}$ Correspondence:

Inna Semenova

innas.od@gmail.com

Specialty section:

This article was submitted to Interdisciplinary Climate Studies,

a section of the journal

Frontiers in Earth Science

Received: 15 August 2018

Accepted: 26 February 2020

Published: 28 April 2020

Citation:

Semenova I and Slizhe M (2020) Synoptic Conditions of Droughts and Dry Winds in the Black Sea Steppe Province Under Recent Decades. Front. Earth Sci. 8:69. doi: 10.3389/feart.2020.00069

\section{Synoptic Conditions of Droughts and Dry Winds in the Black Sea Steppe Province Under Recent Decades}

\author{
Inna Semenova* and Mariia Slizhe \\ Odessa State Environmental University, Odessa, Ukraine
}

The features of regional atmosphere circulation, which are accompanied simultaneously by two high impact hydrometeorological phenomena (such as droughts and dry winds) in the Black Sea Steppe zone of Ukraine were considered. Dry wind as a complex phenomenon is widespread throughout Ukraine during the warm season of the year. Dry winds often accompany a drought, but they appear as peripheral processes in contrast to the droughts, which are usually formed in the central parts of anticyclones. The number of days with dry winds at the Steppe stations varies on average from 10 to 20 cases to $40-50$ cases per warm season, while in the coastal zone the number of days decreases sharply due to a common increase of air atmospheric relative humidity. Analysis of the interannual dynamics of dry winds showed that the number of days with dry winds increases significantly in seasons characterized by a high aridity, according to values of the drought index used. Two time intervals with high and low frequency of seasonal droughts and dry winds were detected during the considered period: 19952015. These phenomena have become more intense after 2004, compared to the previous decade. Backward trajectories of air particles showed that the most cases of dry winds originate in air masses, which form up to 5 days previously at the surface level to the east or north-east outside of the territory of Ukraine and then pass into the study area within 5 days.

Keywords: dry wind, drought, drought index, anticyclone, air mass trajectory

\section{INTRODUCTION}

The territory of Ukraine is exposed to droughts of different intensities and durations almost every year. Meteorological (or agroclimatic) seasonal droughts are widespread. The Ukrainian Steppe encompasses most of the western segment of the Eurasian Steppe, known as the Black Sea Steppe province or Pontic (Figure 1). The border between the Forest-Steppe and the Steppe is not distinct. The Steppe occupies about $40 \%$ of the territory of Ukraine and belongs to the driest areas of the country (Kubiiovych and Husar Struk, 1993).

The Steppe stores the greatest heat resources in Ukraine and has the longest growing season, but receives the least precipitation and often suffers from drought. The relatively moderate climate and growing season that lasts between 210 and 245 days allows for the cultivation of heat-loving crops, and even doubles cropping. But the annual precipitation decreases southward from $450 \mathrm{~mm}$ along the forest-steppe margin to $300 \mathrm{~mm}$ at the coastal plain. The moisture deficit, generated by an average annual evaporation of $900-1,000 \mathrm{~mm}$, is in part compensated by a summer precipitation maximum, just when the plants need more water. 
The climate in the Black Sea Steppe province has undergone significant changes over a relatively short period, from the end of the 20th century through to the beginning of the 21st century (Semenova, 2015). At the end of the 20th century the winter temperatures were close to climate conditions. But in the first decade of the 21 st century positive temperature anomalies $(+0.2$, $+0.4^{\circ} \mathrm{C}$ ) were observed. The end of the 20th century showed small negative anomalies of summer temperatures. In the first decade of the 21st century strong positive temperature anomalies (up to $+1.5^{\circ} \mathrm{C}$ ) are observed. This means that winters and, especially, summers have become warmer. On the other hand, summer precipitation in the Black Sea Steppe province was close to climatic average at the end of the 20th century. But in the first decade of the 21 st century there was a strong decline in precipitation, especially in the Western Steppe. So, the current climate is characterized by hot and dry summer conditions, which often lead to drought.

As is well known, drought is a normal, recurring feature of climate. It occurs in high and low rainfall areas and in virtually all climatic regimes. Generally, a natural drought is defined as a negative deviation of hydrometeorological parameters (e.g., precipitation, soil moisture, river flow, groundwater level etc.) from the climatic mean condition. A shortage of weather-related water supply is usually caused by a deviation of precipitation, soil moisture and river discharge that constitute meteorological, agricultural and hydrological droughts, respectively. Socioeconomic drought is defined as a lack of weather-related water supply needed to meet the normal water demands for human activities.

There is still no universal method to describe all droughtrelated processes due to the complexity drought phenomena. The main approach to drought assessment is to use different drought indices such as hydrometeorological non-standardized drought indices [e.g., Hydro-thermal Coefficient of Selyaninov (HTC), Palmer Drought Severity Index (PDSI)] and more flexible and allapplicable standardized indices [e.g., Standardized Precipitation Index (SPI), Standardized Precipitation Evapotranspiration Index (SPEI)] as well as satellite-based indices [e.g., Vegetation Condition Index (VCI), Vegetation Health Index (VHI)] (Svoboda and Fuchs, 2016).

In some cases, drought may be accompanied by dry and hot winds, locally named "Sukhovei," that cause additional damage (Buchinskij, 1976; Schubert et al., 2014). Suchovey is associated with high impact weather conditions, causing strong winds under high air temperatures and low relative humidity that causes vegetation stress. Sukhovey, or the same type of wind in the steppes and semi-desert areas of Eurasia, emanate from the deserts of Africa, Asia Minor, southern Kazakhstan, or Central Asia.

Under dry winds, the main factor determining the level of damage to plants is the state of the water balance of the leaves, dependent on inflows-outflows of water in the leaves. In the field, at an air temperature of $35-37^{\circ} \mathrm{C}$, in most plants the stomatal apparatus stops normally regulating the evaporation, which greatly accelerates the drying process in leaves during dry winds. Damage from dry winds occurs due to partial or complete drying of leaves, appearance of brown spots on them, and early yellowing and falling from the trees (Zolotokrylin, 2010). One to two days of dry winds can cause desiccation of flowers and sterilization of pollen, which is especially dangerous for cereals in the stages of ear emergence and flowering. At the later growing stages, dry winds lead to early ripening and desiccation of not fully ripened grain. Under insufficient soil moisture content (below 30\%), the impact of dry winds during the milk development stage can cause a decrease in the crop of 13-18\% and during the ear stage on 20-25\% (Buchinskij, 1976).

Early studies of Zuberbiller E.A. and Romushkevich V.I., developed by Buchinskij (1970) showed that dry winds in the former Soviet republics occur under certain synoptic conditions, which move air masses from the northern regions southward with their subsequent transformation. In any case, the processes of dry wind formation are associated with the evolution of anticyclones in the region.

The relationship of dry winds in the Ukraine with Azores baric ridges, which spread to the east, was established in the 1970s (Volevakha and Romushkevych, 1972). Other cases of dry winds occur on the western periphery of the anticyclone, with its center located to the east outside the country, as well as on the south periphery of an anticyclone with Arctic origin. In the steppe area, dry winds may also form under the influence of summer thermal depression as a result of local air mass transformation. Dry winds, which originate under propagation of western ridges, are prevalent in Ukraine.

In Ukraine the anticyclone type of weather can last for a year. There are some types of the anticyclone trajectories, such as Scandinavian types, which most commonly occur in the west and north-west (Kivganov and Goloshchak, 1998). In the warm period, anticyclones are often related to the Azores high, which produces western and south-western trajectories of anticyclones. As shown by Martazinova and Sologub (2000) and Martazinova and Sverdlik (1998), in the last decades due to some eastward shifting of location of the Azores high (in relation to the climatic norm of 1950-1974) there are more frequent western ridges over the territory of Ukraine, where the anticyclone usually becomes stationary. According to this, three types of synoptic processes were identified, which lead to the propagating of warm dry air over the territory of Eastern Europe. The first type is related to the air masses which move from the west and connect to the Azores high. The second type is related to the meridional structure of the baric field and is characterized by air flow from the south. The third type is characterized by penetration of the territory of Ukraine by warm continental air on the southern periphery of an anticyclone located over the Urals. All types of these synoptic processes can be an origin of hot and dry winds.

The latest published study contains data on dry wind frequencies in Ukraine for 1991-2000 (Tatarchuk and Barabash, 2007). The set of weather stations presented in this paper differs from our study. For most stations, comparison is possible only with climatic data, e.g., the monograph of Buchinskij (1976), where the periods of 1936-1964 and 1945-1964 are available. Also, a difficulty in comparing studies of dry winds for different periods and in different countries is the absence of a unified concept and criteria for this phenomenon. In the meteorology of the former Soviet Union, the geophysical criterion of the dry 


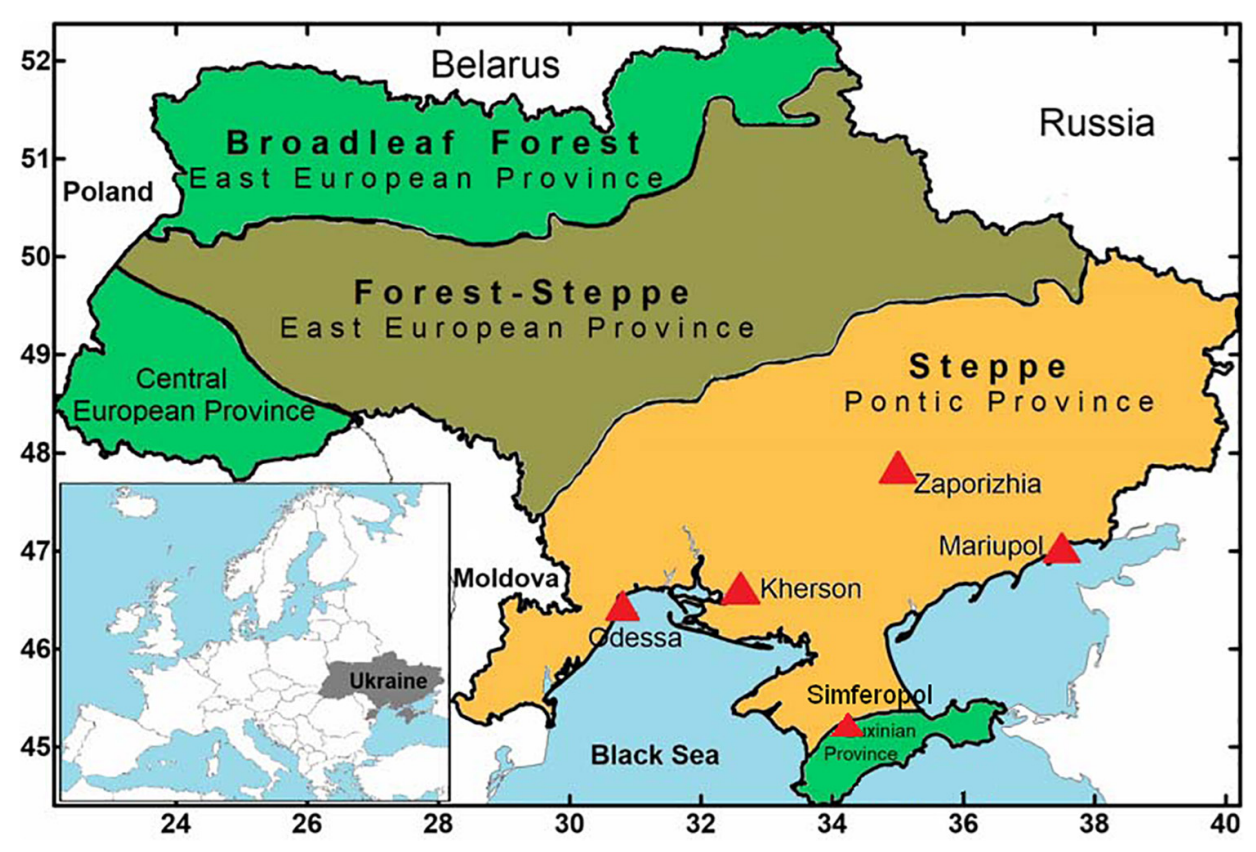

FIGURE 1 | The map of Ukraine with the location of meteorological stations (red triangles) in the Black Sea Steppe province, and schematic location the territory of Ukraine on the map of Europe. Frontiers Media SA remains neutral with regard to jurisdictional claims in published maps and institutional affiliations.

wind as a complex phenomenon combined the simultaneous action of three factors: temperature, humidity and wind. This criterion is in contrast to biophysical ones, evaluates only the atmospheric conditions, and does not include the effect on plants (Lipinskiy et al., 2003). In agroclimatic references of Ukraine, the biophysical criterion of Zuberbiller (1959) is used, because it indirectly takes into account the reaction of plants to the influence of sukhovey.

Lydolph (1964) wrote about the complexity of understanding the Russian term "Suchovey" noting that is a phenomenon that differs in origin and in nature from local winds such as a foehn or sirocco. "So significant are they that outstanding occurrences have been tagged with specific names, and in many instances these occurrences are so classic in form that the Russian descriptive terms have been accepted the world over. Such a term is "sukhovey." The word itself means dry or drought. "Zasukha" is the Russian word that is directly analogous to the English word "drought"... "Sukhovey" refers to individual spells of hot dry flows of air which have immediate and profound effects on vegetation... It is rapid wilting of vegetation that best identifies the sukhovey."

The sukhovey is typically defined as prolonged periods of dry weather when dry, hot air circulates around the periphery (often to the south) of a high-pressure system. However, as shown by Volevakha and Romushkevych (1972), in Ukraine- especially in the steppe regions- the occurrence of a dry, hot wind is possible both in the warm sector of cyclones and in conditions of summer thermal depressions. Such winds are usually short-term but can be intense and destructive for vegetation. As shown by Buchinskij (1976) the dry winds usually last for 2-4 days, but the extreme events span 2-3 weeks. According to the author's studies
(Slizhe and Semenova, 2017a,b), in 1995-2015 at Ukrainian weather stations in April-May, 1-day sukhovei occurred in more than $90 \%$ of cases. In the summer months, 1-day sukhovei were observed on average in $60 \%$ of cases; dry winds of a duration of 2-4 days were found in 30-35\% of cases. Sukhovei of longer durations were observed in less than $10 \%$ of cases.

The indicated features of the sukhovey phenomenon define the main task of this study as an update of information on the spatiotemporal distribution of dry, hot winds and the synoptic conditions of their formation in southern areas of Ukraine in the last few decades.

\section{MATERIALS AND METHODS}

This study evaluates the dynamics of droughts during AprilAugust of 1995-2015. The assessment is based on the Standardized Precipitation Evapotranspiration Index (SPEI), whose time series were obtained from the Global $0.5^{\circ}$ gridded SPEI database (Global SPEI database, 2018). The SPEI was introduced by Vicente-Serrano et al. (2010) and is based on monthly precipitation data and potential evapotranspiration data, which depends on air temperature. Air temperature is especially important in the warm season and under global warming, when evapotranspiration increases.

The SPEI may be defined for various time intervals. Short time intervals (from one to a few months) shows short- and medium-range conditions of moistening and provide a seasonal assessment of precipitation; therefore, these scales are widely used for detecting meteorological and agroclimatic droughts. A drought event for a selected time scale is defined as a period 
in which the SPEI is continuously negative. Drought intensity is defined for values of the SPEI with the following categories: values from 0 to -0.99 correspond to mild drought; from -1.00 to -1.49 correspond to moderate drought; from -1.50 to -1.99 correspond to severe drought; values less than -2.00 characterize an extreme drought.

In our study, a 6 month period was applied to detect growing period drought (from April to August). According to criteria from the Hydrometeorological service of Ukraine, the dry wind is identified if, in at least one observation, values of the meteorological parameters simultaneously are: air temperature $25^{\circ} \mathrm{C}$ and higher, wind speed at $10 \mathrm{~m}$ height is $5 \mathrm{~m} / \mathrm{s}$ or more, and relative air humidity is $30 \%$ or lower (Lipinskiy et al., 2003). In such conditions, water quickly evaporates from the soil, causing damage to crops and grains.

An assessment of the spatiotemporal distribution of dry winds was done using station observations for air temperature, humidity, and wind at the five meteorological stations of Ukraine, located in the coastal zone of the Black Sea and Sea of Azov, from April to August of 1995-2015 using the Climate data Online [CDO], 2018.

For determination of the sea level pressure (SLP) patterns for periods with dry winds in the southern areas of Ukraine, we selected days in which this phenomenon was observed. The composite pressure fields were built using the NCEP/NCAR reanalysis using the NOAA Earth System Research Laboratory (NOAA/ESRL, 2018).

To study the regions in which the dry winds originate, the HYSPLIT modeling system of Air Resources Laboratory NOAA (Stein et al., 2015; READY. NOAA Air Resources Laboratory, 2018) was used to build backward trajectories of air particles at the sea level pressure surface and at the levels of 1,500 and 3,000 $\mathrm{m}$ for the period of $120 \mathrm{~h}$ ( 5 days). For this purpose we selected periods in which dry winds were maximally widespread over the study area that is, in which the sukhovey was observed at the largest number of stations simultaneously.

\section{RESULTS AND DISCUSSION}

During 1995-2015, warm season droughts in the Black Sea Steppe province were observed during more than one half of the period. Mild drought occurred 11 times, moderate drought was observed 3 times, and severe drought appeared once. Extreme drought covered the Steppe zone in the growing season of 2007 (Figure 2). The time series of SPEI values show that drought prevailed in the Ukrainian Steppe every year after 2007, which correspond to the observed negative anomalies of precipitation and positive anomalies of temperature at this period as shown earlier.

Studies of drought frequency have shown a prominent decrease in long drought events ( $\geq 6$ months) in Ukraine for 1951-2012 (Spinoni et al., 2016). Also, drought severity and duration tended to decrease in Ukraine, but along the Black Sea coast these parameters have shown an increase. So, the considered period from 2007 may be the beginning of a change in drought characteristics, which tend to strengthen in the southern region of Ukraine.

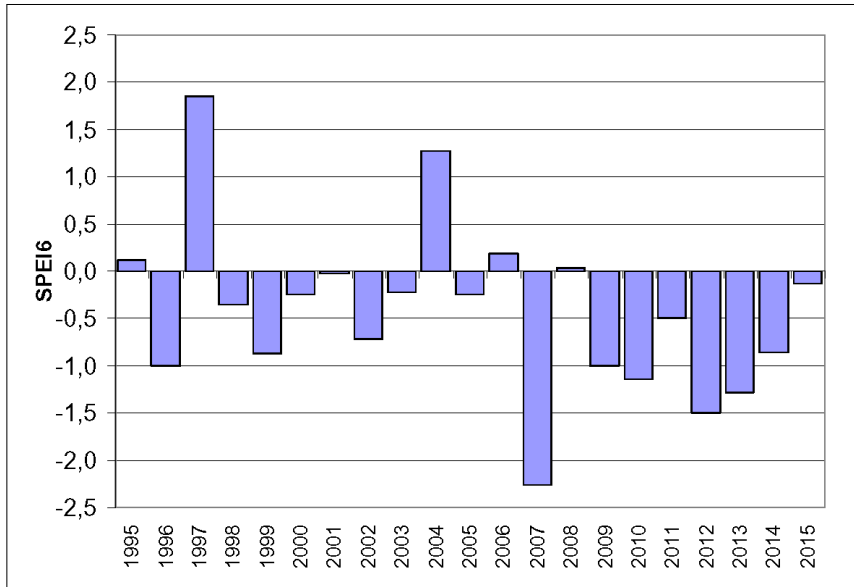

FIGURE 2 | Time series of the SPEl at 6-months time scale (April-August) during 1995-2015.

Analysis of dry wind frequencies showed an increase of the number of days with dry winds in 1996, 2000-2003, 2007, and 2012-2013 (Figure 3A). As seen, in these years the largest negative values of the index SPEI were noted (compare with Figure 1). In these years, as shown by Cherenkova et al. (2015), over the East European Plain during the vegetation period an anticyclonic pressure field was dominant, accompanied by blocking processes, which led to the formation of extensive droughts. In 1997 and 2004, all stations observed the lowest number of days with dry winds, while at the same time the index SPEI reached its highest positive values.

In general, we can see two periods with different patterns of dry winds: 1995-2004 with low frequencies and 2005-2015 with high frequencies. The average number of days with dry winds in the second period is two times higher than for the first at almost all stations except Kherson. Analysis of the linear trends of number of days with dry winds using an F-test statistic showed that this increase is significant at the 95\% confidence level for four stations, excluding Kherson where the interannual variability is small during the study period.

Analysis of the frequency of dry winds by month showed that the sum of days increases from April to August (Figure 3B), when the dry winds appear most frequently (excluding Kherson, where the maximum is observed in July). The total sum of days with dry winds in August varies from 107 days in Mariupol to 215 days in Simferopol.

Most frequently dry wind durations of 1 day and 2-4 days are observed. During the study period, the total number of 1day dry winds ranged from 69 days in Mariupol to 132 days in Odessa. The number of episodes with 2-4-day dry winds varied from 30 cases in Kherson to 84 cases in Zaporizhzhia. At other stations, the number of cases with dry winds with a duration of 57 -days ranged from 9 cases in Odessa to 19 cases in Simferopol. Dry winds with a duration of 8-10 days or more are rare; their number at stations was 2-6 cases for the entire period. Prolonged episodes of dry winds from 5 days or more were not observed at Kherson. 

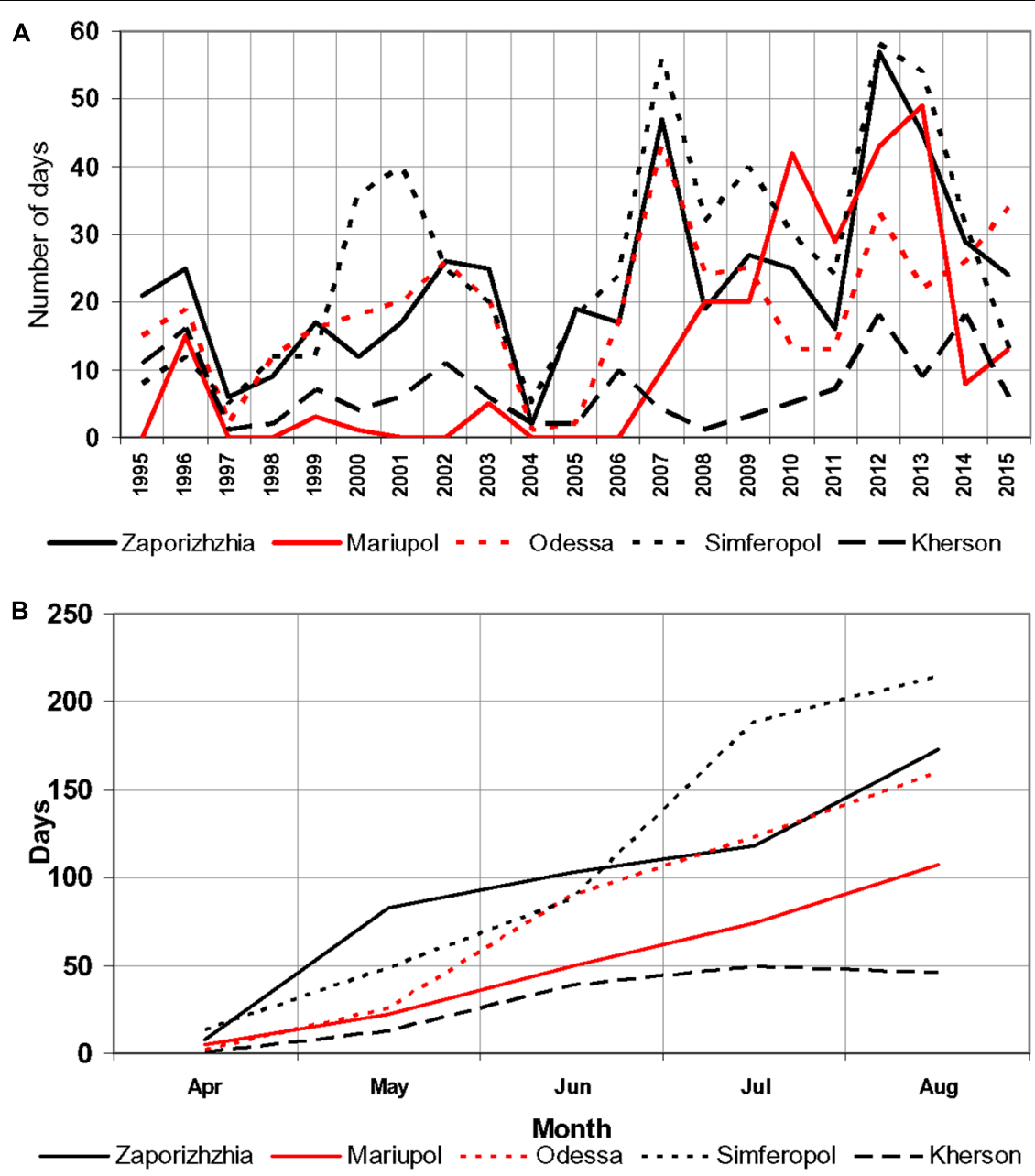

FIGURE 3 | Dynamics of the total number of days with dry wind (A), and the total sum of days with dry wind (B) by months of growing season (April-August) of 1995-2015 at the stations located in the Black Sea Steppe province.

In some cases meteorological parameters during the dry wind phenomenon can reach extreme values. Thus, the maximum air temperature of $40.0^{\circ} \tilde{\mathrm{N}}$ was observed on August 8 and 10, 2010 in Zaporizhzhia and on July 23, 2007 in Odessa. The maximum wind speed of $15 \mathrm{~m} / \mathrm{s}$ was observed on August 29, 2011 in Simferopol. The relative air humidity during the dry wind in Odessa in five cases fell to $4 \%$.

As seen, a complex criterion used to define sukhovey at the weather stations contains meteorological parameters that are very sensitive to local conditions, even within the same synoptic situation. Therefore, the frequency of the dry wind events at stations located in the steppe zone will be determined by their location in relation to water basins and the prevailing wind direction. The greatest number of cases of dry winds, as can be seen in Figure 3, is observed in Zaporizhia and Simferopol, which are located at a distance from the sea (see Figure 1). The minimum number of days with a dry wind is observed in Kherson, which is located close to the Black Sea coast and the delta of Dnieper River, which ensures high humidity in the area and reduces the risk of a dry wind. At stations located in the coastal zone, during the summer period, the increase in humidity and decrease in air temperature is significantly affected by the development of sea breezes that could also lead to reductions in the number of days with sukhovey. It should be noted that the study presents the results for Odessa-airport, which is located at a distance of $6 \mathrm{~km}$ from the coast, which increases the probability of suchovey. In Mariupol in summer, the breezes develop weakly due to the warm sea surface of the Sea of Azov and the shallow Taganrog Bay. Therefore, the seasonal advection of dry and hot air masses from the continental surface with north-eastern winds prevails in this region, which can provide a high frequency of days with dry winds.

The analysis of the SLP fields composited on days with dry wind showed some interesting features. In April and May, dry winds appear in Ukraine, when the territory of central Europe is under a stationary cyclone, which is especially deep in April (Figures $\mathbf{4 A}, \mathbf{B}$ ). Thus the territory of Ukraine is located on the peripheral area, with dry and warm air flow from the south and south-east between a westerly cyclone and ridges to the south-east and north of the Russian Plain. 

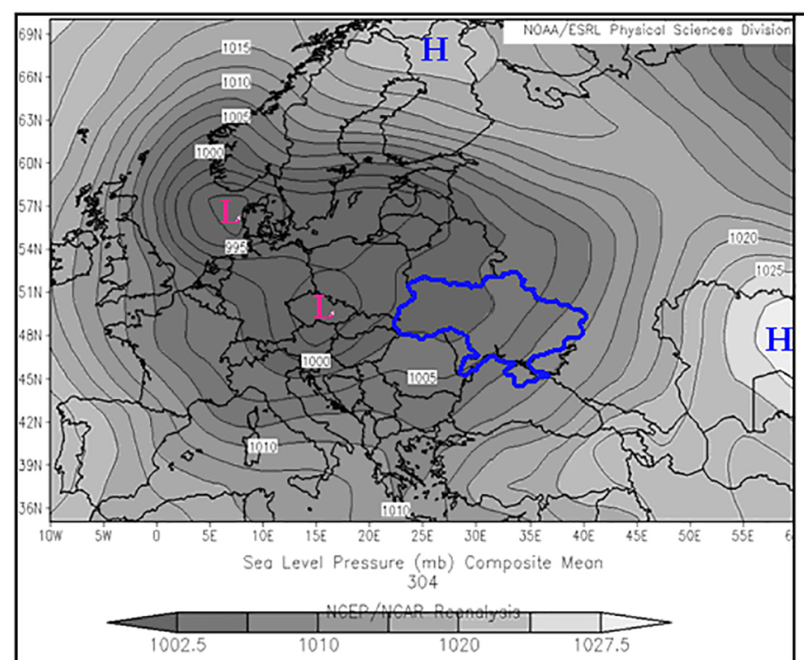

(A) April

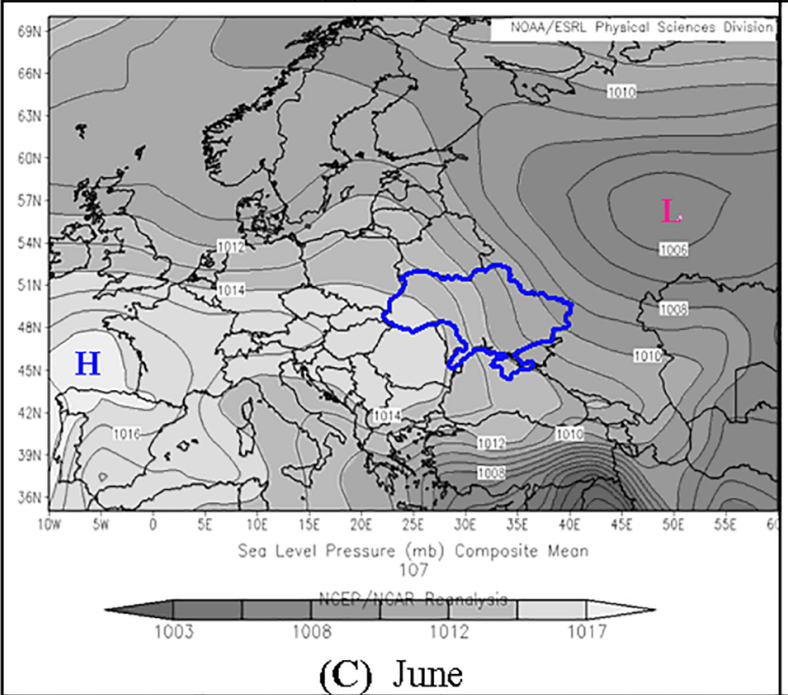

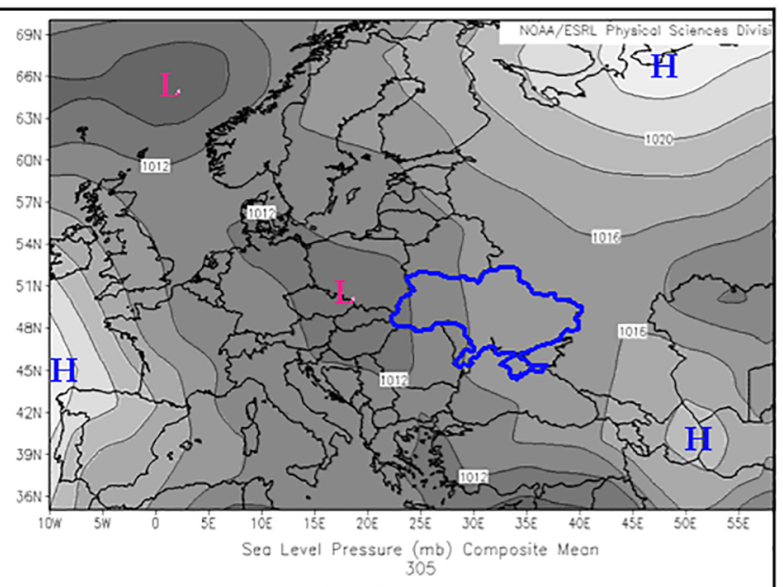

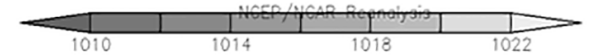

(B) May

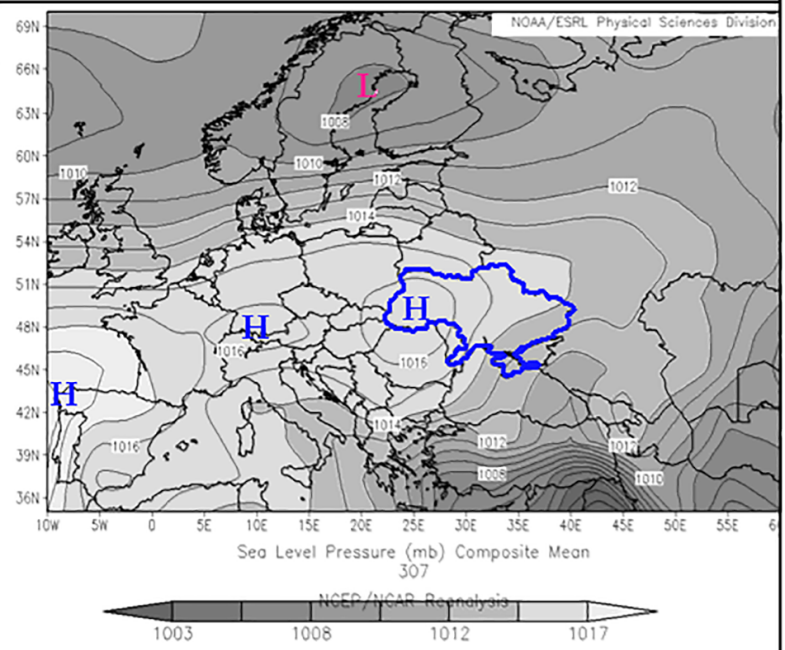

(D) July
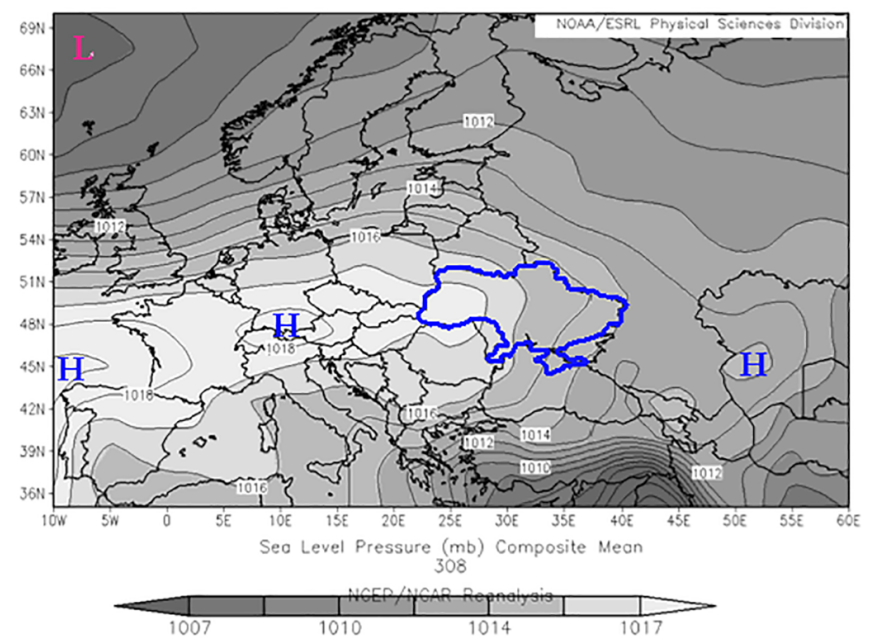

(E) August

FIGURE 4 | Sea level pressure fields averaged for days with dry winds in the Black Sea Steppe province for the months of warm season (territory of Ukraine is marked). (A) April; (B) May; (C) June; (D) July; (E) August. 


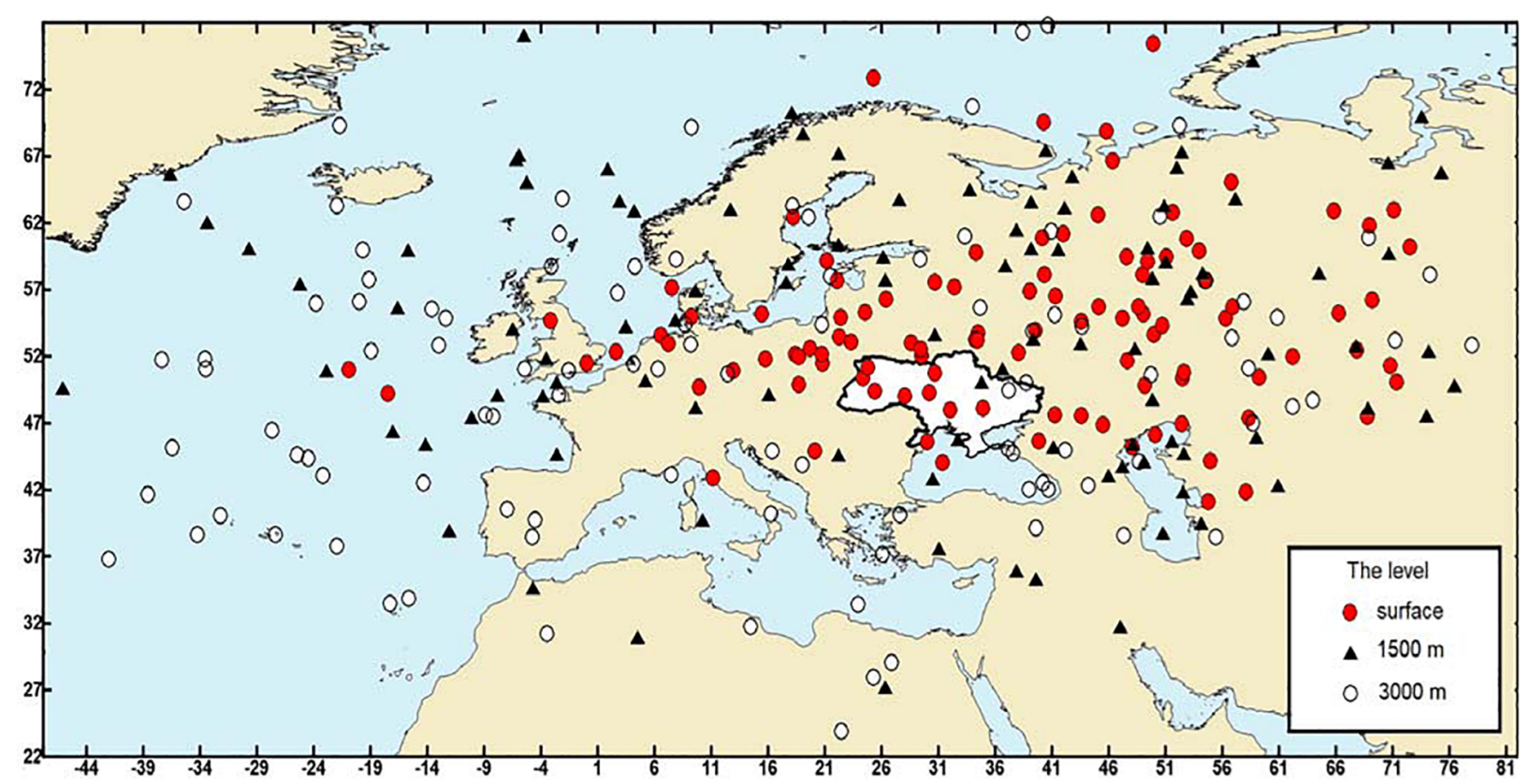

FIGURE 5 | Initial points of 5-day backward trajectories of air masses particles for periods with dry winds at the meteorological stations located in the Black Sea Steppe province.

In June the pressure fields transform to the summer type of circulation, characterized by propagation eastward toward the ridges of the Azores high, which reach up to the territory of Ukraine quite often (Figure 4C). Dry north-western and north winds in the Steppe are formed in the transitional area, with high gradients between the Azores ridge and the low-pressure field over the Russian Plane.

In July and August, the SLP patterns are similar, therefore in both months in southern areas of Ukraine dry winds are formed on the eastern periphery of anticyclones over central and Eastern Europe connected with the Azores ridges (Figures 4D,E). Dry winds in the Steppe have mainly a north-east direction.

On the whole, the obtained SLP patterns for the last few decades show correspondence to those considered in early studies of the synoptic processes accompanied by dry winds in the steppe regions of Ukraine. Therefore, we were interested in the geographic localization of the regions of air mass formation, which come to the Black Sea Steppe province and transform into dry winds while moving. In early research (Volevakha and Romushkevych, 1972), it was shown that about 55\% of the trajectories of air mass particles coming as dry winds originate in the lower troposphere of the Arctic basin and come to the Caspian lowland or to the Lower Volga region and then pass to the Ukraine. About $20 \%$ of the trajectories pass from the Atlantic coast directly to the territory of Ukraine along the northern periphery of well-developed anticyclones eastward toward the Azores. Some trajectories (12\%) begin in the south or south-east of Central Asia or Iran. Other cases of dry winds are related to stationary anticyclones located over the center of the Russian Plain.

In synoptic meteorology a well-known method for constructing the backward trajectories of air particles is used to determine the regions of formation of air masses and their temperature and humidity characteristics (David et al., 2010). In our study, 5-day backward trajectories of air particles were analyzed using the HYSPLIT model at three levels for the four above-mentioned stations located in the Black Sea Steppe province. In total, we built 318 trajectories for the days with dry winds.

Figure 5 shows the initial points of trajectories relative to the territory of Ukraine, which correspond to the regions of origin of air masses from which dry winds appear. At the surface level the trajectories are most frequent, which start in the north-east $(27 \%)$ or to the east $(18 \%)$ outside the territory of Ukraine. From the west and the north, air masses come in $16 \%$ of cases. A significant number of trajectories (14\%) begin within the territory of the country. There were no cases of air particles moving at the surface level from the south and south-west for our dataset of dry wind days.

At the $1,500 \mathrm{~m}$ level (corresponding to an isobaric surface of $850 \mathrm{hPa}$ ) air masses with dry winds most often originate in the west (25\%) outside of Ukraine. Also, air particles often travel from the north-east (18\%) or from the north-west (16\%), traveling more rarely from the north (11\%). In the other directions there are only single cases of trajectories.

At the 3,000 m level (corresponding to an isobaric surface of $700 \mathrm{hPa}$ ) more than half of the trajectories of air particles begin in the west (45\%) and northwest (13\%) outside the territory of Ukraine. The frequency of other directions, from where air particles come, is almost the same and is $7-9 \%$ of cases. Several cases of the initial points of trajectories within the territory of Ukraine, as well as to the south-west of it, are noted. 
Although this analysis refers to all cases of dry winds over the entire warm period, a comparison with the mean pressure fields in the future will allow for more details of monthly and seasonal features of the air masses trajectories to be established.

As mentioned above, the question of the relationship between drought and dry winds was raised in some earlier studies. It should be noted that these phenomena occur on different time scales, wherein the dry wind, by definition, does not depend on precipitation as a drought. However, it is obvious that the transformation of the moving air mass, which leads to a sharp decrease in the air relative humidity, must occur quickly.

According to our preliminary studies of the three-dimensional structure of the air mass movement, in most cases air particles moving at different levels at the same time move downward, therefore the adiabatic descent of the air mass is occurring. In addition, analysis of the initial points of air particles in Figure 5 shows that at the surface level for 5 days, air particles usually move several hundred kilometers, and at high atmospheric levels move thousands of kilometers before reaching the steppe regions of Ukraine. In this case, additional drying and warming of the air mass will occur if it moves over dry areas and soils, which are already affected by drought.

The reverse interaction of dry winds and droughts was also found. An increase of wind speed at high air temperatures enhances evapotranspiration, which accelerates the process of drying the soil. If the precipitation deficit continues at the same time, this process will lead to agricultural drought and reduce the crop as a result. But formal verification of the sukhovey occurrence for months with drought, or months without drought, showed that $15-35 \%$ cases of dry winds occurred non-concurrently with drought (Semenova and Slizhe, 2019). Drought events were determined using SPEI index on a 1-month time-scale for each weather station. This result emphasizes the fact that a sukhovey can be considered as a separate phenomenon that occurs independently of drought but which does not exclude the interaction of both phenomena. The process of interaction between drought and dry winds resembles a phenomenon described as a "flash drought," which is characterized by a rapid rate of intensification (according to Otkin et al., 2018). It seems that dry winds can act as a trigger mechanism in the rapid development of drought, when the drought severity index falls to a critical value during a short time period. Examining this however, would require the adaptation of drought indicators and dry wind criteria to identical time scales that enable these phenomena to be correctly compared.

\section{CONCLUSION}

As the territory of Ukraine is one of the most important agricultural areas in eastern Europe, spring-summer droughts and dry winds can considerably worsen productivity of grain crops or even completely damage them. The increasing aridity of the current climate requires the timely estimates of risks of developing seasonal droughts, by considering the trends of arid phenomena.
The results obtained in this study clearly demonstrate that during the two most recent decades the Black Sea steppe province has been characterized by a significant increasing frequency of droughts and dry winds. The frequency of drought in the growing season especially increased after 2007, since when extreme drought has prevailed over the Black Sea Steppe province. The interannual dynamics of dry wind frequencies demonstrates the opposite tendency to SPEI values, that is, with a decrease in the values of the index, the number of days with dry winds increases as would be expected.

The structure of pressure fields in the lower troposphere plays a decisive role for both droughts and dry winds, with the main elements being persistent cyclones and anticyclones, as well as their peripheral areas with high pressure gradients where dry winds are observed. Analysis of the SLP fields for days with dry winds showed that in the spring months in the Black Sea steppe province southerly and south-easterly dry winds are observed on the eastern periphery of stationary cyclones located over central Europe. In the summer months, the main SLP pattern providing dry winds in the Steppe is the intense development and propagation of the ridge of the Azores high toward centraleastern Europe. In this case, northerly and north-easterly winds appear on the eastern periphery of these ridges.

Detailing the air particles trajectories shows that dry winds appear in air masses which, at the surface level, form mainly from the east or north-east outside the territory of Ukraine, but at higher atmospheric levels the western component of the flow prevails. Planned further studies of the three-dimensional temperature-humidity structure of flow in the lower troposphere will make it possible to establish a mechanism for transformation of the air mass that leads to formation of dry wind phenomenon.

\section{DATA AVAILABILITY STATEMENT}

The datasets of station data for this study can be found in the Climate data online (CDO), NOAA-NCDC, https://www. ncdc.noaa.gov/cdo-web. The datasets of the SPEI index for this study can be found in the Global SPEI database, http: //spei.csic.es/database.html. The datasets of the NCEP/NCAR reanalysis for this study can be found in the NOAA/ESRL. Physical Sciences Division, https://www.esrl.noaa.gov/psd/data/ reanalysis/reanalysis.shtml.

\section{AUTHOR CONTRIBUTIONS}

The tasks for IS are as follows: setting of the research problem; definition of the algorithm and research methods; review of the relevant publications; analysis of time series of the drought index; comparative analysis of the frequency of droughts and dry winds; analysis of the mean pressure fields; writing the abstract and body of the manuscript. The tasks for MS are as follows: creation of the dataset for dry winds using meteorological criteria for selected stations; analysis of the frequency of dry winds at the stations; construction and analysis of the mean pressure fields; construction the trajectories of air particles and analysis of the regions of formation the air masses. 


\section{REFERENCES}

Buchinskij, I. E. (1970). Droughts, Dry Winds and Dust Storms In Ukraine and The Fight Against Them. Kiev: Urozhaj.

Buchinskij, I. E. (1976). Droughts and Dry Winds. St. Petersburg: Gidrometeoizdat.

Cherenkova, E. A., Semenova, I. G., Kononova, N. K., and Titkova, T. B. (2015). Droughts and dynamics of synoptic processes in the south of the East European Plain at the beginning of the twenty first century. Arid Ecosyst. 5, 45-56. doi: $10.1134 / \mathrm{s} 2079096115020055$

Climate data Online [CDO] (2018). NOAA-NCDC. Available at: https://www.ncdc. noaa.gov/cdo-web (accessed August 10, 2016).

David, M. H., Luke, S., Robert, E. D., David, B. K., Stephen, D. G., Michael, L. D., et al. (2010). A back-trajectory and airmass climatology for the Northern Shenandoah Valley, USA. Int. J. Climatol. 30, 569-581.

Global SPEI database (2018). Available at: http://spei.csic.es/database.html (accessed February 2, 2018).

Kivganov, A. F., and Goloshchak, O. P. (1998). Anticyclones of the Eastern Europe. Meteorol. Climatol. Hydrol. 35, 81-90.

Kubiiovych, V., and Husar Struk, D. (1993). Encyclopedia of Ukraine. Toronto: University of Toronto Press.

Lipinskiy, V. M., Djachuk, V. A., and Babichenko, V. M. (eds) (2003). Climate of Ukraine. Kiev: Raevskyy Publishing House.

Lydolph, P. E. (1964). The russian sukhovey. Ann. Assoc. Am. Geograph. 3, 291-309.

Martazinova, V. F., and Sologub, T. A. (2000). Atmospheric circulation, which forms drought conditions on the territory of Ukraine at the end of the 20th century. Sci. Proc. UkrGMI 248, 36-47.

Martazinova, V. F., and Sverdlik, T. A. (1998). Large-scale atmospheric circulation of the 20th century, its change and its present state. Sci. Proc. UkrGMI 246, 21-27.

NOAA/ESRL (2018). Physical Sciences Division (PSD). Available at: https://www esrl.noaa.gov/psd/data/reanalysis/reanalysis.shtml (accessed November 22, 2017).

Otkin, J. A., Svoboda, M., Hunt, E. D., Ford, T. W., Anderson, M. C., Hain, C., et al. (2018). Flash droughts: A review and assessment of the challenges imposed by rapid-onset droughts in the United States. Bull. Amer. Meteor. Soc. 99, 911-919. doi: 10.1175/BAMS-D-17-0149.1

READY. NOAA Air Resources Laboratory (2018). Available at: https://ready.arl. noaa.gov/HYSPLIT_traj.php (accessed July 17, 2017).

Schubert, S. D., Wang, H., Koster, R. D., Suarez, M. J., and Groisman, P. (2014). Northern Eurasian heat waves and droughts. J. Clim. 27, 3169-3207. doi 10.1175/jcli-d-13-00360.1

Semenova, I. G. (2015). "Climate conditions and droughts in the black sea steppe province under the modern period and the near future," in Poster at the Program Book: XIX INQUA Congress: Quaternary Perspectives on Climate Change, Natural Hazards and Civilization. 112-112. (Poster No. P06-P01). Available at: http://inqua2015.jp/program/INQUA2015program.pdf
Semenova, I., and Slizhe, M. (2019). Distribution of Dry And Hot Conditions In Ukraine At The Present Time And Near Future. The Workshop On Correlated Extreme Events. New York, NY: Columbia University.

Slizhe, M. O., and Semenova, I. G. (2017a). Spatiotemporal distribution and meteorological characteristics of hot dry winds in Ukraine at the end of XX - beginning of the XXI century. Bull. Odessa State Environ. Univer. 22, 21-29.

Slizhe, M. O., and Semenova, I. G. (2017b). Hot dry winds of different length in Ukraine in the early ÕOI century. Sakharov Readings 2017: Environmental Problems of the 21st Century: materials of the 17th int. scientific conf. may 18-19, 2017, minsk, republic of belarus. Sci. Conf. 2, $179-180$.

Spinoni, J., Naumann, G., Vogt, J., and Barbosa, P. (2016). Meteorological Droughts in Europe: Events and Impacts - Past Trends and Future Projections. Luxembourg: Publications Office of the European Union.

Stein, A. F., Draxler, R. R., Rolph, G. D., Stunder, B. J. B., Cohen, M. D., and Ngan, F. (2015). NOAA's HYSPLIT atmospheric transport and dispersion modeling system. Bull. Amer. Meteor. Soc. 96, 2059-2077. doi: 10.1175/BAMS-D-1400110.1

Svoboda, M., and Fuchs, B. A. (eds) (2016). Handbook of Drought Indicators And Indices. Integrated Drought Management Programme. Geneva: World Meteorological Organization and Global Water Partnership.

Tatarchuk, O. G., and Barabash, M. B. (2007). Study of the spatiotemporal distribution of dry winds in the territory of Ukraine under modern climate conditions. UkrHMI Sci. Pap. 256, 140-154.

Vicente-Serrano, S. M., Beguería, S., and López-Moreno, J. I. (2010). A Multiscalar drought index sensitive to global warming: the standardized precipitation evapotranspiration index - SPEI. J. Clim. 23, 1696-1718. doi: 10.1175/ 2009jcli2909.1

Volevakha, V. O., and Romushkevych, V. I. (1972). Dry Winds in Ukraine. Kiev: University of Kiev.

Zolotokrylin, A. N. (2010). "Dry winds, dust storms and prevention of damage to agricultural land," in Natural Disasters, ed. V. M. Kotlyakov (Singapore: EOLSS/UNESCO), 1-18.

Zuberbiller, E. A. (1959). Agrometeorological Characteristics Of Dry Winds Leningrad. St. Petersburg: Gidrometeoizdat.

Conflict of Interest: The authors declare that the research was conducted in the absence of any commercial or financial relationships that could be construed as a potential conflict of interest.

Copyright (C) 2020 Semenova and Slizhe. This is an open-access article distributed under the terms of the Creative Commons Attribution License (CC BY). The use, distribution or reproduction in other forums is permitted, provided the original author(s) and the copyright owner(s) are credited and that the original publication in this journal is cited, in accordance with accepted academic practice. No use, distribution or reproduction is permitted which does not comply with these terms. 